\title{
Bilecik Belediyesi Yaşayan Şehir Müzesi ve Yaşama Katkıları
}

\section{Bilecik Municipality Living City Museum and Its Contributions to Life}

\section{Serap Buyurgan}

Prof. Dr., Başkent Üniversitesi, Güzel Sanatlar Tasarım ve Mimarlık Fakültesi, Görsel Sanatlar ve Tasarım Bölümü email: sbuyurgan@baskent.edu.tr (DORCID ID: https://orcid.org/0000-0001-8858-2161

\section{Gizem Büke Öztürk}

Öğr. Gör., Bilecik Şeyh Edebali Üniversitesi, Söğüt MYO, İç Mekân Tasarımı Programı email: buke.dogru@bilecik.edu.tr (DORCID ID: https://orcid.org/0000-0002-7071-053X

\begin{abstract}
$\checkmark$ iThenticate" Bu makale bilimsel etik ve kurallara uygun hazırlanmış ve intihal incelemesinden geçirilmiştir. Etik kurul onayı gerektirmemektedir.
\end{abstract}

Atıf (APA 6)/To cite this article

Buyurgan, S., \& Öztürk, G. B. (2021). Bilecik Belediyesi Yaşayan Șehir Müzesi ve yaşama katkıları. Atatürk Üniversitesi Güzel Sanatlar Enstitüsü Dergisi, 27(46), 271-284. https://doi.org/10.35247/ataunigsed.845628

Makale Gönderim Tarihi/Received: 23/12/2020

Makale Kabul Tarihi/Accepted: 10/02/2021

Makale Yayın Tarihi/Published: 30/03/2021

Review Article/Derleme Makalesi

$\ddot{O} z$

Müzeler, tarihi, sanatsal, kültürel, teknoloji ve doğaya ait alanlarda geçmiş, bugün ve gelecek sentezini en iyi yapan, içlerinde sergilediği dünyayı en etkili öğrenebileceğimiz heyecan verici öğrenme mekanlarıdır. Müzeler sergiledikleri eserlere göre farklı türlerle karşımıza çıkarlar. Araştırmada, Bilecik ilinin her yönüyle; tarih, kültür, sanat, günlük yaşam vb. alanlarındaki gelișimini ve yaşanmıșlıklarını etkili sergileme yöntemleri ile gözler önüne seren, yaptığı etkinliklerle bu değerleri bugüne ve geleceğe taşıyan Bilecik Belediyesi Yaşayan Şehir Müzesinin amacı ve oluşum süreci, eserlerini sergileme yöntemleri ve öğrencilere, halka yönelik etkinlikleri ile yaşama katkıları değerlendirilmiștir. Araștırma tarama yöntemi ile yapılmıștır. Araştırma sonucunda, Bilecik Belediyesi Yaşayan Şehir Müzesinin Bilecik'te yaşamıs uygarlıkları, boyları, bu uygarlıkların kültürel izlerini, Bilecik'in sosyal ve kültürel yapısını, unutulmaya yüz tutmuş zanaatlarımızı gözler önüne serdiği ve öğrencilere ve halka yönelik canlı performans ve etkinliklerle canlandırdığı görülmüştür.

Anahtar Kelimeler: Bilecik Belediyesi Yasayan Sehir Müzesi, Müzenin Yaşama Katkıları, Müzede Öğrenme, Müze Etkinlikleri, Eser Sergileme

\begin{abstract}
Museums are learning venues that make the best synthesis of past, present, and future in historical, artistic, cultural, technological, and natural fields, and where we can learn the world most effectively with exhibitions. Museums appear in different genres according to the exhibited works. In this research, Bilecik Municipality Living City Museum's purpose and formation process, the methods of exhibiting works of art, and students' activities for the public and their contribution to life were evaluated. The research has been done by survey method. As a result of the research, it has been observed that Bilecik Municipality Living City Museum reveals the civilizations that lived in Bilecik, their descendants, the cultural traces of these civilizations, the social and cultural structure of Bilecik, our forgotten crafts and activates them with live performances and activities for students and public.
\end{abstract}

Keywords: Bilecik Municipality Living City Museum, Contributions of Museums, Learning in The Museum, Museum Activities, Exhibiting Works of Art

\section{Giriş}

Geçmişi tarih öncesi yıllara dayanan müze kavramı, etimolojik kökenini tanrıların kralı Zeus ve bellek tanrıçası Mnemosyne'nin kızları olan Müzlerden ya da Musalardan almaktadır. Yunanca "İlham Perileriee olarak nitelendirilse de zaman içerisinde bilimler tapınağ geçmişi hatırlama, unutmama, koruma görevlerini üstlenmeleri açısından kutsal mekân olarak görülmelerini sağlamıştır (Dönmez ve Kılınçer, 2011, s. 104). Akaların en büyük tanrıları Zeus'un (Romalılar Jüpiter diyor) dokuz tane kızı vardır. Bu dokuz kız şarkı söyleyerek, raksederek tanrı Apollon'a refakat ederler. Bu kızlar eski Yunan Panteonu'nda nağme ve şiir ilham eden mabudelerdir. Kızlardan her biri güzel sanatlardan birini himaye eder. Atina' da bir tepede müzlere tahsis edilen binaya müze adı verilir ve müze kelimesi buradan alınarak dünyaya yayılır (Sapolyo, 1936, s. 8-10). Müzenin bir mekân olarak temellerini ilk olarak İskender'in ölümünden sonra Mısır'da hüküm süren Ptoleme sülalesinden Ptoleme Filadef atmıştır (aktaran Buyurgan ve Mercin, 2010, s. 72). İnsanlar, insanlık tarihi boyunca, unutmaya ve unutulmaya karşı sürekli bir direniş göstermiştir. İnsan sürekli bir gelişim ve değişim içerinde olmuştur. İnsan eğer sadece konuştukları ile kalsa ve konuşulanları hatırlasa geçmişin bilinmesi ve hatırlanması imkânsız olurdu. İnsanlar, her türlü belge, bilgi ve nesneyi kendinden sonra gelen kuşaklara iletebilme yeteneğine ve özelliğne sahip olmuştur. İşte insanlar, unutulmaya karşı verilen bu mücadelede her türlü tarih yazıcılığını, kütüphaneleri, arşivleri ve müzeleri oluşturmuştur (Gerçek, 1999, s. 2). Zaman içerisinde gelişen müze kavramı 17. yüzyılda antik nesneleri betimlemek için kullanılır, 18.yy'da bir koleksiyonu koruyan, sergileyen ve halka açan kuruluş olarak tanımlanırken, 19.yy'da ulusal boyutta, toplumun geçmiş izlerinin, yeniden hatırlandığ mekanlar haline gelir (aktaran Altunbaş ve Özdemir, 2012, s. 4; Onur, 2012, s. 20). 
1946 yılında tüm dünyada müzeler arası işbirliğini ve gelişimini sağlamak için ICOM (Uluslararası Müzeler Konseyi) kurulmuştur. ICOM, bir sivil toplum kuruluşu olarak hizmet vererek, dünyanın doğal, somut ve somut olmayan kültürel mirasının bugün ve gelecekte korunmasını ve devamlılığının sağlanmasını hedeflemektedir. Ayrıca müze alanında tek sivil toplum kuruluşu olarak bugün 138'den fazla ülkede, 118 ulusal ve 32 uluslararası komite ile müze faaliyetlerini aralıksız devam ettirebilmek için mesleki ve etik standartlar belirleyip, önerilerde bulunan, bilginin gelişim göstererek yayılmasını teşvik eden bir konumdadır (Akyol Kasapoğlu, 2020, s. 75). ICOM Dünya Savaşları sonrasında savaşların yıkıcı etkilerine karşı 'evrensel' değerler oluşturma, insanlığın ortak değerlerini koruma ve sergileme konularında yapıcı adımlarla insanlığa hizmet etmektedir.

ICOM'un 7 Eylül 2019 tarihinde Japonya Kyoto’da Uluslararası Konferans Merkezi’nde (ICC Kyoto) düzenlemiş olduğu 25. Olağanüstü Genel Kurul'da (Extraordinary General Assembly/EGA), geçerli olan müze tanımında değişikliğe gidilerek, yeni müze tanımı yapılmış ve ICOM Tüzüğüne güncel tanım dahil edilerek resmileşmiştir. Yeni müze tanımına göre,

Müzeler, geçmiş ve gelecek hakkında kritik diyaloglar için demokratikleştirici, kapsayııı ve çok sesli (polifonik) alanlardır. Bugünün çatışmalarını ve zorluklarını kabul edip ele alarak, toplum adına korumakla yükümlü oldukları eserleri ve örneklerini gelecek nesiller için güvence altına alır, her kesimden insanın bu kültürel mirasa erişimi için eşit haklar sağlar. Müzeler kâr amaçlı değildir. Katılımcı ve şeffaftırlar ve insan onuruna ve sosyal adalete, küresel eşitlik ve küresel refah düzeyine katkıda bulunmayı amaçlayan dünya anlayışlarını toplamak, korumak, araştırmak, yorumlamak, sergilemek ve geliştirmek için çeşitli topluluklarla aktif ortaklıklar içerisinde çalışırlar (ICOM, 2019, para. 4-5).

Uluslararası Müzeler Konseyinin tanımdan da anlaşılacağı gibi müzelerin içinde bulunduğumuz dönemin ihtiyaçlarını karşılayabilecek, bütüncül bir kültür ve eğitim merkezi olarak tanımlandığı; aynı zamanda da toplumun farklı kesimlerine ulaşarak paylaşımcı bir anlayış benimsemeleri sayesinde geçmişin hafızasını koruma ve yaşatmada önemli bir misyona sahip oldukları görülmektedir. Zaman içerisinde gelişim gösteren müze kavramı günümüzde başlangıcından çok farklı noktalara gelmiş ve sadece sanatsal objelerin ya da doğa nesnelerinin sergilendiği mekanlar olmaktan ziyade içinde bulunduğu toplumu sosyal, psikolojik, toplumsal ve kültürel yönleriyle inceleyerek eğitici bir misyon üstlenmiştir. Bu özelliğiyle müzelerin eğitim amaçlı kullanılması oyun ve öğrenmeyi teşvik etmek adına tasarlanmış farklı özellikler içeren öğrenme ortamları olarak okul dışı öğrenme ortamları arasında yerini almıştır. Özellikle on dokuzuncu yüzyılda müzelerin öğrenmedeki rolüne dikkat çekilerek, başta gelişmiş ülkeler olmak üzere müzelerin öğrenmedeki rolü etkin olarak kullanılmaya başlamıştır. Buyurgan ve Buyurgan'a (2020, s. 68) göre "Müze, sanatsal, bilimsel, geleneğe ait, tarihi, teknoloji ve doğaya ait alanlarda, geçmişin, bugünün izlerini içinde barındıran, görerek, işiterek, uygulama yaparak, hatta yaşayarak öğrenenin gerçekleştiği, halka açık heyecan verici öğrenme mekanlarıdır”. Müzeler bireylere dokunma ve sorgulama yoluyla keşfetmeleri ve onlara heyecan verici nesneler sunma açısından zengindir; çeşitli matematik, sanat ve sosyal bilim kavramlarını keşfetmeleri için benzersiz firsatlarla doğrudan öğrenme ortamı sunar (Andre, Durksen ve Volman, 2017, s. 47-48). Okullardaki eğitim anlayışından çok farklı eğitim ortamı sunan müzeler, öğrencilerin ilgisini çekme, onları eğitme, anlamaya teşvik etme ve en önemlisi gelecekteki öğrenmeleri için sorumluluk almalarına yardımcı olması açısından önemlidir (aktaran Eshach, 2007, s. 186-188).

Müzeler sergiledikleri eserlere, eserlerini sergiledikleri mekanlara, bağlı oldukları yönetim birimine, hizmet ettikleri bölgeye, hitap ettikleri kitleye ve işlevlerine göre çeşitlendirilebilir. Belediyelere bağlı kent müzeleri, bağll oldukları yönetim birimlerine göre müzeler başlığı altında değerlendirilebilir.

Perouse'nin de belirttiği gibi yaşanmışlıklar bütünü ve ortak hafıza olan kentsel belleğin bir yansıması olan kent müzeleri açılmaya başlanır. Kent müzeleri tamamen klasik müzelerden farklı, çağdaş-yeni müzeciliğin bir ürünüdür (aktaran Albasan, 2020, s. 19). Şehirler geçmiş yaşanmışlıkları bugüne getiren, geçmişin değerlerini koruyarak yarınını oluşturan merkezler olduklarından; şehirlerin tarihi, kültürü, geleneği, kısacası tüm belleği şehir müzelerinde yer almakta ve yaşatılmaktadır. İnsanların yaşadıklarını hatırlamak ve hatırlatmak, sonraki nesillere ortak bir geçmiş sunabilmek adına kurulan kent/şehir müzeleri, farklı köklerden gelen insanları dil, din, ırk ayrımı gözetmeksizin ortak bir kültürle harmanlamak ve onlara ortak bir kimlik kazandırmayı amaçlamaktadır (Çekül Vakfi, 2013, s. 17).

19. yüzyılın sonlarında ilk olarak Avrupa'da kurulmaya başlayan kent müzeleri; Avrupa'nın farklı bölgelerinden gelen Amerika'ya göç eden göçmenlerin kentlerin geçmişini ve bu kentlerde yaşayan kişilerin tarihlerini belgelemek istemeleri doğrultusunda gelişim göstermiş̧tir. İlk etapta Avrupa'da Ulusal kimliğin ön planda olduğu ulusal müzeler yer alırken, zaman içerisinde kent vurgusunu taşıyan, içerisinde birçok kültürün yar aldığ kent müzeleri kurulmaya başlanmıştır. $\mathrm{Bu}$ dönemde kent müzelerinin gelişiminde Fransa ve İngiltere aktif rol oynamıştır. Bu anlamada 1880 yılında İlk kent müzesi Fransa Paris’te kurulan Carvalet Müzesi ve sonrasında İngiltere'de Londra Kent Müzesi açılmıştır (Albasan, 2020, s. 16). Zaman içerisinde çalışmaların aralıksız devam ettirilmesi ile Avrupa'nın pek çok kentinde kent müzeleri kurulmuş ve günümüzde de kurulmaya devam etmektedir. Yunanistan-Atina Kent Müzesi, Fransa- Strazburg Kent Müzesi, İngiltere- Liverpool Müzesi, 
Slovakya- Bratislava Kent Müzesi, Almanya- Rüsselsheim Kent Müzesi gibi pek çok kent müzesi bulunmaktadır. $\mathrm{Bu}$ örnekler arasında tarihi eskilere dayanan Londra Kent müzesi, 1975 yılında iki müzenin koleksiyonlarının birleştirilmesi sonucu oluşturulmuştur. 1826 yılında kurulan Guidhall Müzesi'nin koleksiyonu daha çok arkeolojik eserler içerirken, 1911 yılında devlete bağlı Londra Müzesi ise, koleksiyonlarında Metropolü yansıtan eserler, aynı zamanda resim, dekoratif sanatlar, giyim ve çeşitli dokuma kumaşlar, toplum ve ev hayatına ilişkin koleksiyonları da içermekteydi. Devletin ve Londra Kent Birliği’nin destekleriyle finanse edilen müze, Londralılar kimlerdir?, Onların hayatını etkilemiş sosyal, ekonomik ve politik etkenler nelerdir?, Londra diğer kentlerden hangi açılardan farklıdır? gibi daha birçok soruya cevap aranmış ve bu cevapların bulunabilmesi adına bir dizi akademik disiplinden veri toplanmıştır. Londra kent müzesinin amacı, Londra kentinin ve halkının tarihini herkes için anlaş1lır hale getirmek olmuştur (Köse, 2010, s. 20-23).

Avrupa'da bu gelişmeler yaşanırken Türkiye'de, 1990'larda gündeme gelen kent müzelerinin kurulmasına yönelik ilk çalışmalar 2000'lerden sonra pratik anlamda yaygınlaşmaya başlamıştır. Bu doğrultuda kent müzelerinin açılmasına yönelik girişimler ilk olarak kentler hakkında kapsamlı araştırma yapılmasını, bilgi ve belge toplama çalışmalarıyla öncelik kazanmaya başlamıştır (Silier, 2010, s. 18-19). 1990 yılında İstanbul'da Yıldız Sarayı bahçesinin içerisinde açılan İstanbul Şehir Müzesi, Türkiye'deki ilk kent müzesi olma özelliği taşımaktadır. 2000 yılında, İstanbul Büyükşehir Belediyesi’nin destekleriyle İstanbul Kent Müzesi projesine başlanmıştır. Günümüzde, Bursa Kent Müzesi, Çanakkale Kent Müzesi, İzmir Ahmet Priştina Kent Arşivi, Mardin Kent Müzesi gibi müzelerimiz kent müzelerimize örnek olarak verilebilir (İhtiyar, 2011, s. 56-62; Silier, 2010, s. 18-21; Çekül Vakfi, 2013, s. 23-29). 2000'li yıllardan günümüze kadar İstanbul dışında Türkiye'nin birçok kentinde kent müzeleri açılmış, söz konusu müzeler Şehir Müzesi, Kent Müzesi, Kent Tarihi ve Kent Arşivi adı altında yer almıştır (Keskin, 2014, s. 34). Bursa Kent Müzesi 1926 yılında adliye binası olarak yapılmış, 2004 yılında işlev değişikliğiyle Bursa Kent Müzesi olarak ziyarete açılmıştır. Müze hem içerik, hem de biçim bakımından dinamik bir yapıya sahiptir. Müze, kentin kültürel, tarihsel, sosyal ve ekonomik zenginliğini tanıtmak ve yarının kentlilerine yol gösterebilmeyi amaçlamaktadır. Bursa Kent Müzesi, kent ile ilgili her türlü belge, eşya, görsel malzeme, kitap, görüntü ve ses kayıtlarını bünyesinde bulundurarak, bu verilere dayalı geçici ve sürekli sergiler düzenleyerek, modern müzecilik anlayışının gerektirdiği vizyonda ziyaretçi ile karşılıklı ilişkiye dayalı interaktif bir ortam oluşturarak Bursa'nın her yönüyle, siyasi, ekonomik, kültürel oluşum sürecini gözler önüne sermektedir (Bursa Büyükşehir Belediyesi, t.y., para. 1-2).

Avrupa ve Türkiye ölçeğinde sürdürülen çalışmalar, artan girişimler sonucunda ülkelerin Kent Konseyleri, Kentler Birliği Platformları, Tarih Vakfı gibi ulusal ve uluslararası kuruluşların da kurulmasıyla kent müzeciliğinin önemi güncelliğini korumakta ve yaygınlaşmaktadır. Bu kapsamda 2004 yılında ICOM (Uluslararası Müzeler Konseyi) tarafından düzenlenen toplantıda kısa adı CAMOC olan Kent Müzeleri Aktiviteleri ve Koleksiyonları için Uluslararası Komite kurulması kararlaştırılmıştır (Keskin, 2014, s. 33).

Tüm bu gelişmeler kent müzelerinin öneminin bir kez daha altını çizmektedir. Öyleyse kent müzeleri her ülkede, halk yaşamı, geleneksel sanatlar, zanaat ve sanat ürünlerinin de sergilendiği, yaşatıldığı, gelecek nesillere taşındığı önemli mekanlardır. Özellikle on dokuzuncu yüzyılda müzelerin öğrenmedeki rolü ve önemi keşfedildikten sonra müzeler, okulların, öğrencilerin, ailelerin, toplumun, farklı engel gruplarının öğrenmesine yönelik etkinliklerle ve heyecan verici sergilemelerle kendilerini ifade etmeye başlamışlardır. Bu bakış açısından hareketle araştırmada, Bilecik Belediyesi Yaşayan Şehir Müzesi'nin amacı ve oluşum süreci, eserlerini sergileme yöntemleri ve özellikle unutulmaya yüz tutmuş kültürel değerlerimizi hatırlatma ve canlandırmaya yönelik etkinlikleri ile yaşama katkıları değerlendirilmiştir.

\section{Yöntem}

Araştırma tarama modelinde yapılmıştır. Genel tarama modelleri, çok sayıda elemandan oluşan bir evrende evren hakkında bir yargıya varmak amacı ile evrenin tümü veya evrenden alınacak bir grup, örnek veya örneklem üzerinde yapılan taramaları kapsar; bu model ile tekil veya ilişkisel taramalar yapılabilir (Karasar, 1991, s. 79). Araştırma verileri literatür taraması ve Bilecik Belediyesi Yaşayan Şehir Müzesi uzmanları ile görüşmelerden elde edilmiş ve yorumlanmıştır.

\section{Bulgular}

\subsection{Bilecik Belediyesi Yaşayan Şehir Müzesi’nin Amacı ve Oluşum Süreci}

Kent müzelerinin oluşması için öncelikle kentlerin tarihi hakkında bilgi edinilmesi ve detaylı araştırılması gerekmektedir. Bilecik ilinin de tarihi çok eski dönemlere dayanmaktadır. İlk yerleşimin MÖ 3000'den önce olduğu ve ilin en eski isimlerinin Agrilion, Agrillum, Belekoma olduğu bilinmektedir. Zaman içerisinde birçok medeniyete ev sahipliği yapan Bilecik, Bizans, Selçuklu ve Osmanlı Dönemlerinde yerleşim bölgesi olarak kullanılmış, Söğüt ilçesi, Osmanlı Devleti’nin kuruluşuna kaynaklık etmiştir. Kent, kurtuluş mücadelesinde büyük oranda mal ve can kayıplarına uğramıştır. Özellikle Bilecik ili bölgenin en önemli ipek endüstrisi merkezleri arasında yer alıp çok sayıda ipekçilik tesisine sahipken, ülkenin milli mücadele sürecinde ekonomik, sosyal ve 
nüfus açısından kayba uğramasıyla, şehir neredeyse yerle bir olmuştur (“T.C. Bilecik Valiliği”, t.y., para. 6). Günümüzde var olan tarihi, kültürel ve ekonomik yöndeki zenginliklerinin yanı sıra, şehir doğal güzellikleri, yeşil alanları, köy yaşantıları ile de varlığını sürdürmektedir. Bilecik Belediyesi Yaşayan Şehir Müzesi tüm bu maddi ve manevi değerlerin korunması, tanıtılması, gelecek nesillere aktarılması amacıyla Bilecik Belediyesi ve BursaEskişehir Bilecik Kalkınma Ajansı'nın (BEBKA) çalışmalarıyla 2017 yılında açılmıştır. Müzenin amacı: taşı mermer, toprağı seramik, yaprağı ipek, kuruluş ve kurtuluşun şehri olan Bilecik'i, tarihi bir bütün olarak kabul eden bilimin gücünden faydalanarak hem Osmanlı Devleti'nin kurulduğu hem de milli mücadeleyi konu alan yılları gelecek kuşaklara anlatmak ve tanıtmaktır (T.C. Bilecik Belediyesi, 2019, para. 1).

BEBKA Proje Sahipliğinde 19 Ekim/19 Kasım 2016 tarihleri arasında gerçekleştirilen projeyle; müze çalışanlarına yönelik eğitim programı, müzede sergileme, koruma, sürdürülebilirlik, bilgilendirme ve yönlendirme tasarımlarını içeren eğitimler verilmiş; böylece müzenin daha etkin ve verimli bir şekilde kapılarını halka açması sağlanmıştır (Mercin ve Dilli, 2017, s. 407-408). Bilecik Belediyesi Yaşayan Şehir Müzesi kent merkezinde 2300 metrekarelik alanda Neo-Osmanlı ile Neo-Klasik mimari tarzda inşa edilmiştir (Şenel Fidangenç, 2018, s. 56-60) (Görsel 1). İki kattan oluşan binada; birinci katta Geçmiş Yüzyıllarda Bilecik, Son Yüzyıllarda Bilecik galerileri yer alırken, ikinci katta Bilecik'in gelenek ve göreneklerinin yaşatıldığı Sosyal Yaşam ve Zanaatlar galerileri ve 2019 yılında müzeye kazandırılan Cumhuriyet Odası galerisi yer almaktadır.

\section{Görsel 1}

\section{Bilecik Belediyesi Yaşayan Şehir Müzesi Dış Mekân}

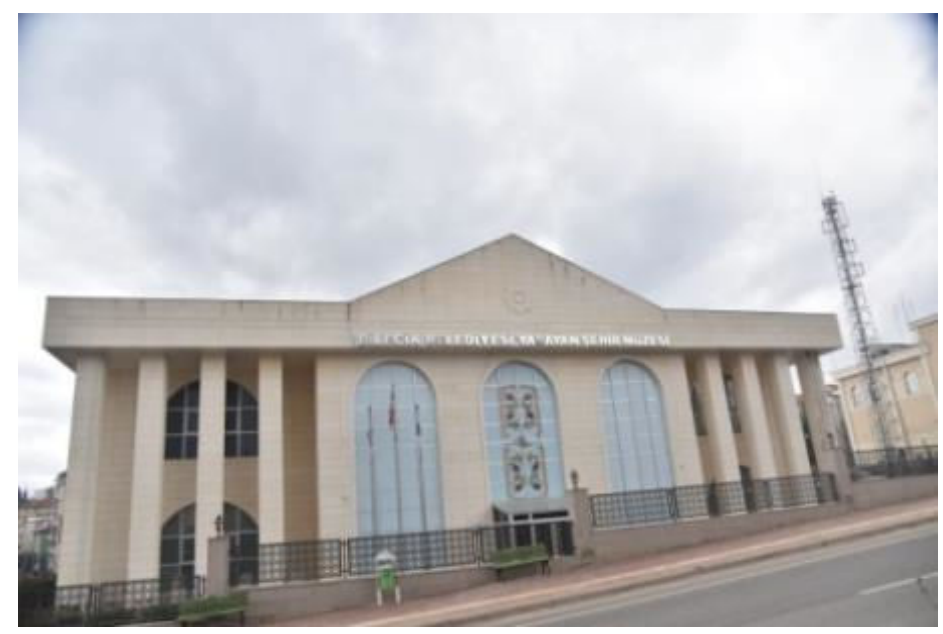

(Öztürk, t.y.a).

2018 yılında kent müzeleri arasında en iyi şehir müzesi ödülüne layık görülen Bilecik Belediyesi Yaşayan Şehir Müzesi tarihi kimliğe sahip kentlerde müzelerin etkin rolüne vurgu yaparak işlevsel bir farkındalık yaratmanın önemini belirtmiştir. 2020 yılında başarılarına bir yenisini daha ekleyen müze, Tarihi Kentler Birliği tarafından düzenlenen "Müze Özendirme Yarışmasında, Kent Müzeleri” kategorisinde ödüle layık görülmüştür (T.C. Bilecik Belediyesi, 2020, para. 1).

Kurulduğu günden bu yana ulusal ve uluslararası gelişmelerle sürekli kendini yenileyen Bilecik Belediyesi Yaşayan Şehir Müzesi gerçekleştirdiği etkinliklerle de toplumla olan bağını her geçen gün güçlendirmektedir. Müze içerisinde yer alan galeriler hem Bilecik kentinin kuruluşunu ve misyonunu anlatırken hem de kentin kültürel, siyasal ve ekonomik özelliklerini aktarmaktadır. Tüm bu özellikleriyle bugün kentin en ilgi çeken ve ziyaret edilen müzeleri arasında yer almaktadır.

\subsection{Bilecik Belediyesi Yaşayan Şehir Müzesi’nde Çağdaş Sergileme Yöntemleri}

Zaman içerisinde gelişim gösteren kültür ve sanata duyulan ilginin artması ülkelerin gelişim düzeylerini de etkileyerek nitelikli insan gücünü doğurmasıyla, Klasik müzecilik anlayışının yerini modern müzecilik anlayışına bırakmıştır. Modern müzecilikle birlikte eserlerin sergilenmesinde ve ziyaretçilere ulaşmasında çağdaş yöntemler kullanarak müzeciliğe yeni bir bakış açısı kazandırılmıştır (Altunbaş ve Özdemir, 2012, s. 5). Özellikle son yıllarda teknolojinin ilerlemesi ve bilgi iletişim olanaklarının gelişmesiyle farklı sergileme yöntemleri müzelerde yer almaya başlamıştır. Müzecilik anlayışının klasik sergileme yöntemlerinden sıyrılarak, günümüz şartlarına uyarlanmasıyla toplumların kalkınma ve girişimcilik düzeylerinde de önemli bir artış yaşanmasını sağlamıştır. Bu sayede günümüz müzecilik anlayışı olan "Modern Müzecilik" teknolojinin sunduğu olanaklar ile interaktif ortamlarda izleyicinin de içinde yer aldığı, uzaktan erişim ile birçok müzeye kolaylıkla erişim sağlanabildiği bir anlayış olarak benimsenmiştir. 
Sergileme müzelerin en önemli işlevleri arasında yer almaktadır. Sözen ve Tanyeli’ye (1992, s. 214) göre, sergileme sanat ürünlerini kamuoyuna sunma işlevi ve etkinliği olarak tanımlamaktadır. Aynı zamanda bilgilendirme ve sergileme yaşamın bir parçası olduğu kadar insan doğasının da bir özelliği olarak nitelendirilmektedir. Günümüzde çağdaş müzecilik kavramı içerisinde, koleksiyonların daha etkili tarzda sergilenmesi için, geleneksel yöntemler yanında, teknolojik araçlardan da yararlanmaktayız. Müzeler, koleksiyonlarının hikâyelerini ziyaretçilerine anlatmak için, kimi zaman basit, kimi zaman da karmaşık anlatım yöntemlerini bir arada kullanabilmektedir. Erbay (2011, s. 89) müzelerde gösterim tekniklerinin çok çeşitli olması nedeniyle 1998 yılında bu teknikler "durağan ve dinamik" gösterim teknikleri olarak sinıflandırılmıştır. Günümüzde kullanılan sergileme yöntemleri durağan ve dinamik gösterim tekniklerinin bir arada kullanımı ile gerçekleştirilmektedir. Müzelerde, özellikle vitrin veya duvarda sergileme, tek başına açık olarak sergileme, canlandırmalar (dijital canlandırmalar, üç boyutlu-balmumu, kil vb.) panoramalar, diyoramalar kullanılmaktadır. Dijital canlandırmalar içerisinde; kiosklar, AR (arttırılmış gerçeklik) gerçek görüntü üzerinden gerçek zamanlı mekân deformasyonu, VR (görsel gerçeklik) video üzerinden bireyin hareketlerine kısıtlı olarak tepki veren animasyonlar, işitsel ve görsel katılımlı sunuşlar, video mapping ve farklı animasyon teknikleri kullanılmaktadır (Buyurgan ve Buyurgan, 2020, s. 90-91).

Çağdaş müzecilik yaklaşımında diğer bir gelişim ise, müze ve izleyici/ziyaretçi arasında iletişimin ve etkileşimin kurulmasıdır. Bunun için müze ziyaretleri rehberler eşliğinde gerçekleştirilmektedir. Ayrıca seminerler, dia-film gösterileri, atölye eğitim uygulamaları gibi birçok etkinlik gerçekleştirilerek, müze gezileri daha eğlenceli ve eğitici bir hal almaktadır. Bilgisayar destekli sergi, dokunmatik ve interaktif sistemler, simülatör gibi teknolojinin getirdiği imkanlar da çağdaş müze yaklaşımlarıyla birlikte kullanılarak etkili sergilemeler gerçekleştirilmektedir. Modern müzecilikte, toplumun her kesimini kucaklayan programlar, etkinlik takvimleri ile müzelerin bir kültür merkezi olarak toplumla bütünleşmesini amaçlamaktadır. Yapılacak etkinliklerin basında, radyoda ve televizyonda duyurulması, müze programlarının afiş veya pankartlarla sergilenmesi, broşür dağıtılmasıyla halkla iletişim kurulmakta ve böylece müze ziyaret alışkanlığı olmayan kesimin de ilgisini çekmeyi hedeflemektedir (Erbay, 2011, s. 75).

Bilecik Belediyesi Yaşayan Şehir Müzesi’nde, Bilecik'te yaşamıș uygarlıklar, boylar, bu uygarlıkların ve boyların kültürel izleri, Ertuğrul Gazi Beyliği’nden Osmanlı İmparatorluğu'na giden yolda yaşanan serüveni, Kurtuluş Savaşı mücadelesinde Bileciğin hikayesi, Bileciğin sosyal ve kültürel yapısı, unutulmaya yüz tutmuş zanaatları üç boyutlu canlandırmalarla, etkili duvar panolarıyla ve canlı, uygulamalı sunuşlarla yaşatılmakta, çağdaş sergileme yöntemleri kullanılarak sergilenmektedir (Buyurgan, Tarlakazan ve Çevik, 2019, s. 112). Müzede klasik müze sergilemelerinde kullanılan vitrin içi (Görsel 2), stant üzeri veya duvarda sergilemeler de yer almaktadır. Yine müzede anlatımı kuvvetlendirmek için dekor, kostüm, fotoğraf, maket, manken, balmumu heykeller, kulaklık ve/veya telefon düzeneğiyle sesli, yönlendiriciler kullanılmakta, sunum zenginleştirilerek ziyaretçinin ilgisini durağan ve dinamik sergilemelerle canlı tutmak hedeflenmektedir. Üç boyutlu Bilecik animasyonları, videolar, animasyonlar, müzik ve ses efektleri gibi interaktif uygulamalarla anlatım desteklenmektedir.

\section{Görsel 2}

Müze İçerisinden Vitrin İçi Sergileme Örnekleri
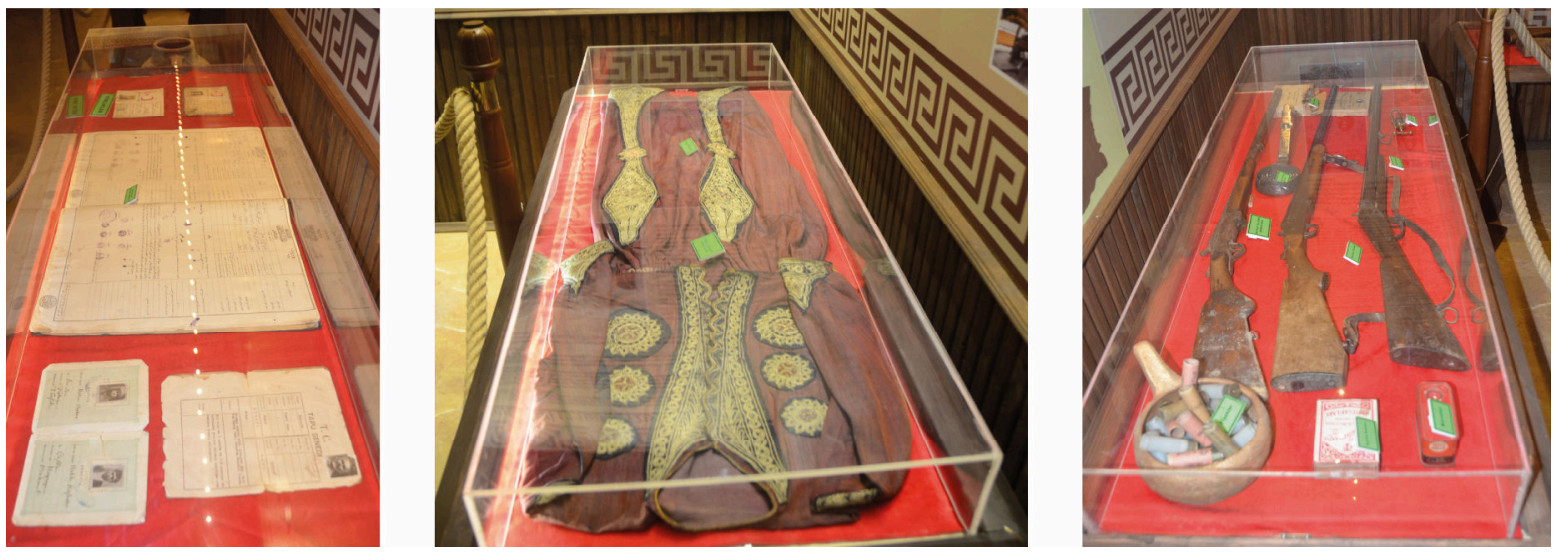

(Öztürk, t.y.b).

Bilecik Belediyesi Yaşayan Şehir Müzesinde sergilenen eserler kronolojik düzen içerisinde ve sergilenen eserin özelliği dikkate alınarak planlanmıştır. Müze içerisinde sergileme beş ana tema üzerinden; birinci katta iki, ikinci katta üç galeri olmak üzere sergileme planlanmıştır. Müze binasının birinci katında Bilecik'in Geçmiş Yüzyıllarda ve Son Yüzyıllarda Bilecik'i anlatan galeriler yer almaktadır. Geçmiş Yüzyıllarda Bilecik galerisinde, Osmanlı Devleti'nin kuruluşu, Ertuğrul Gazi'nin Söğüt'e gelişi, Ertuğrul Gazi, Şeyh Edebali, Osman Gazi, Dursun Fakih gibi Osmanlı Devleti'nin kurulmasında yer alan önemli isimlere yer verilmiş, Şeyh Edebali'ni sözleri 
seslendirilerek o dönem canlandırılmaya çalışılmıştır. Aynı zamanda Bilecik ilinin o zamanlara ait nüfus hareketleri ve iktisadi yapısı da anlatılmıştır. Son Yüzyıllarda Bilecik’i anlatan ikinci galeri, I. İnönü ve II. İnönü Muharebesi, Müdâfaa-i Hukuk Cemiyetleri, Bilecik ve Çevresinde Kurulan Milli Müfrezeler, Tarihi Bilecik Buluşması, İşgal Yıllarında Bilecik, Bilecik’te İstiklal Madalyası alan kişilerin sergilendiği ve tanıtıldığı galeridir. Bu galeride ayrıca "3 Boyutlu Ay Yıldız Platformu” içerisinde Mücadele Dönemlerini konu alan anlatımlar, ses efektleri eşliğinde sergilenmektedir (Görsel 3). Ayrıca bu galeride Bilecik ve çevresinde oluşan ilk uygarlıklardan, Osmanlı Dönemi'ne ve Kurtuluş Savaşı yıllarına uzanan Bilecik tarihini konu alan bilgiler de yer almaktadır. Kayıların sosyal hayatını konu alan Otağ Çadırı (Görsel 4), Şehir Kahvesi, Hatıra Kayı Parası Basım Kütüğü ve Şehir Dükkanlarına da yer verilmiştir. Müze içerisinde yer alan Sosyal ve Zanaat Galerisinde Bilecik yöresine özgü müzikler yer almakta, Geçmiş Yüzyıllarda Bilecik galerisinde Şeyh Edebali'ni sözleri seslendirilmekte, Son Yüzyıllarda Bilecik galerisinde ise top sesleri ile o dönem canlandırılmaya çalışılmaktadır.

\section{Görsel 3}

3 Boyutlu Ay Yıldız Platformunun Yer Aldı ̆̆̆ Kurtuluş Odası

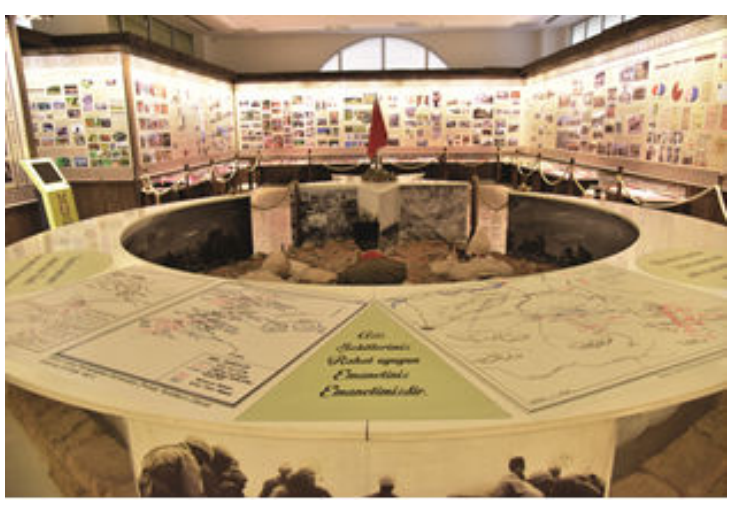

(Bilecik Belediyesi Yaşayan Şehir Müzesi, t.y.a).

\section{Görsel 4}

Kayı Otă̆ Çadırının Yer Aldı̆̆ Kuruluş Odası

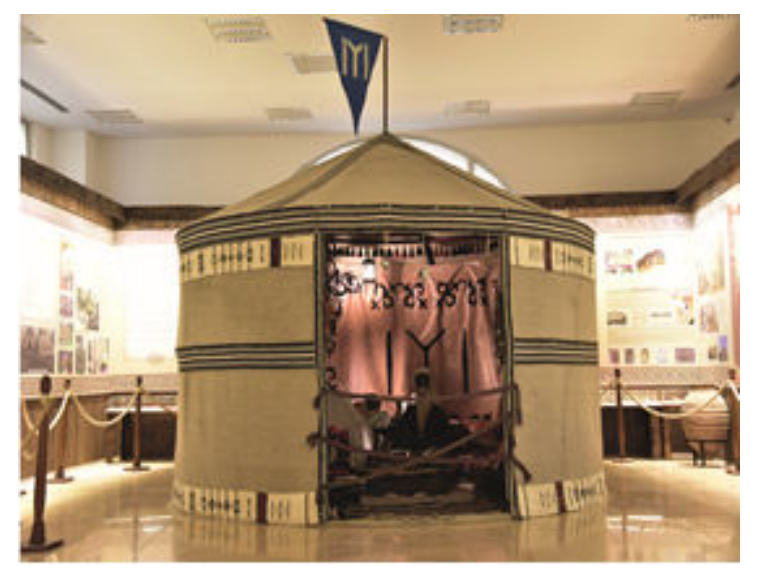

(Bilecik Belediyesi Yaşayan Şehir Müzesi, t.y.b).

Müzenin ikinci katında (Görsel 5), gündelik hayata konu olan Sosyal ve Zanaat Galerileri yer almaktadır. Bu galerilerde şehrin sosyo-kültürel yaşantısı aktarılmakta, günümüzde teknolojik gelişmeler sonucunda unutulmaya yüz tutmuş ancak kent ile özdeşleşmiş zanaatlar Bilecik yöresine özgü müzikler eşliğinde sergilenmektedir. Sosyal Yaşam galerisinde, şehrin yaşam şekillerini konu alan geleneksel konut mimarisinin ayrılmaz parçası olan avlu, mutfak, misafir odaları gibi mekanlar sergilenirken, Bilecik'e özgü gelin odası, kına gecesi gibi gelenekler canlandırmalarla tanıtılmaya çalışılmaktadır. Zanaat odasında, sepetçilik, yorgancılık, çömlekçilik, ipek böcekçiliği, dokumacılık, ayakkabıcılık, demirci ve terzi gibi meslekler sergilenmektedir (Görsel 6). Zanaatlar galerisinde her zanaatin tanıtılması video gösterimleriyle desteklenmektedir. 


\section{Görsel 5}

Bilecik Belediyesi Yaşayan Şehir Müzesi Üst Kat Görseli

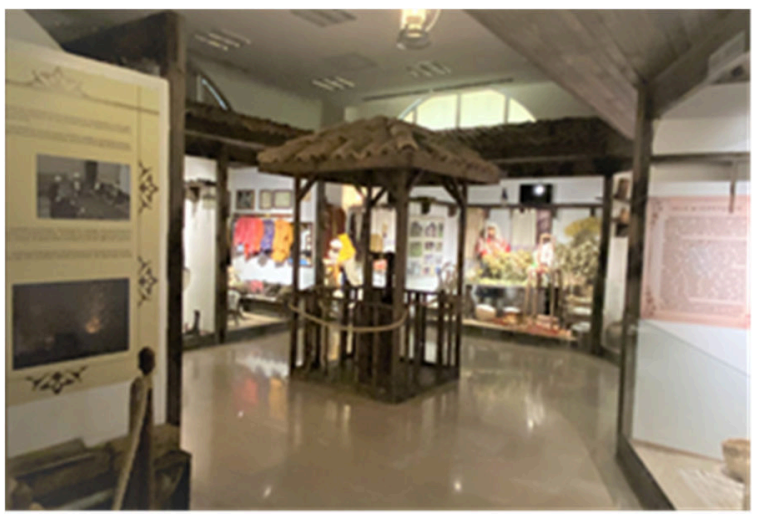

(Öztürk, t.y.c).

\section{Görsel 6}

Müze İçerisinde Sepetçilik, Yorgancılık, Çömlekçilik, Dokumacılık
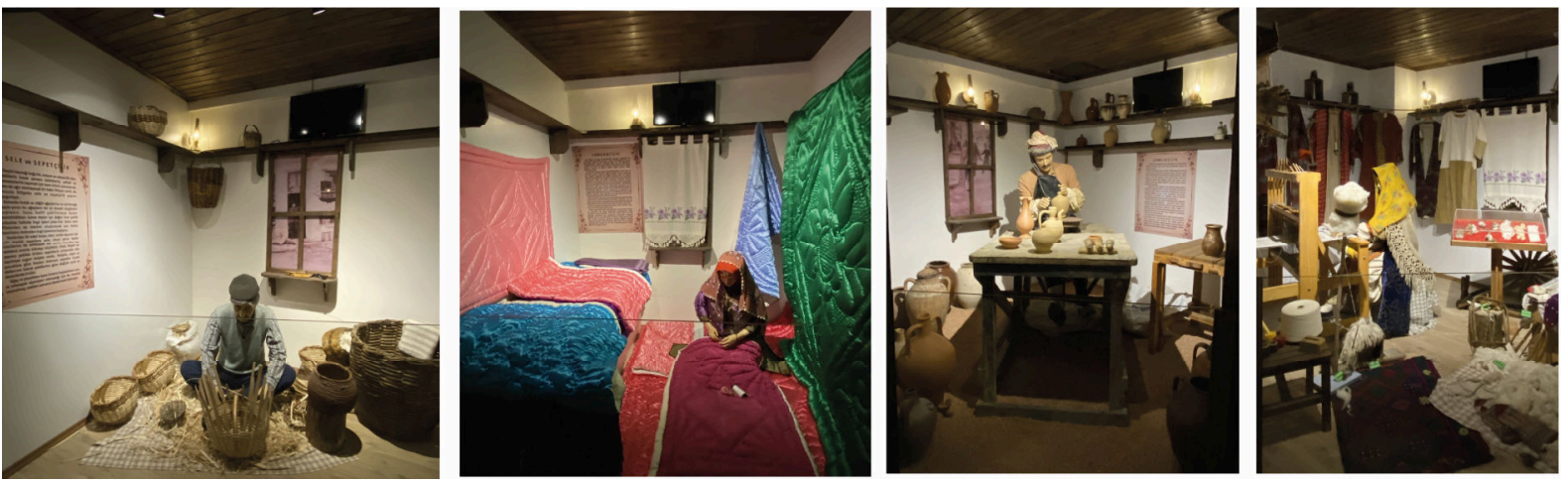

(Öztürk, t.y.d).

İkinci katta yer alan diğer bir galeri müze koleksiyonuna 2019 yılında kazandırılan Cumhuriyet Odası'dır. Cumhuriyet Odası'nda dönemin yaşantısını anlatan iç mekân düzenlemeleri yer alırken o dönem kullanılan oturma grubu, gramofon, piyano, avizeler, dokuma halılar ile yaşatılmakta ve sergilenmektedir (Görsel 7).

\section{Görsel 7}

Cumhuriyet Odast
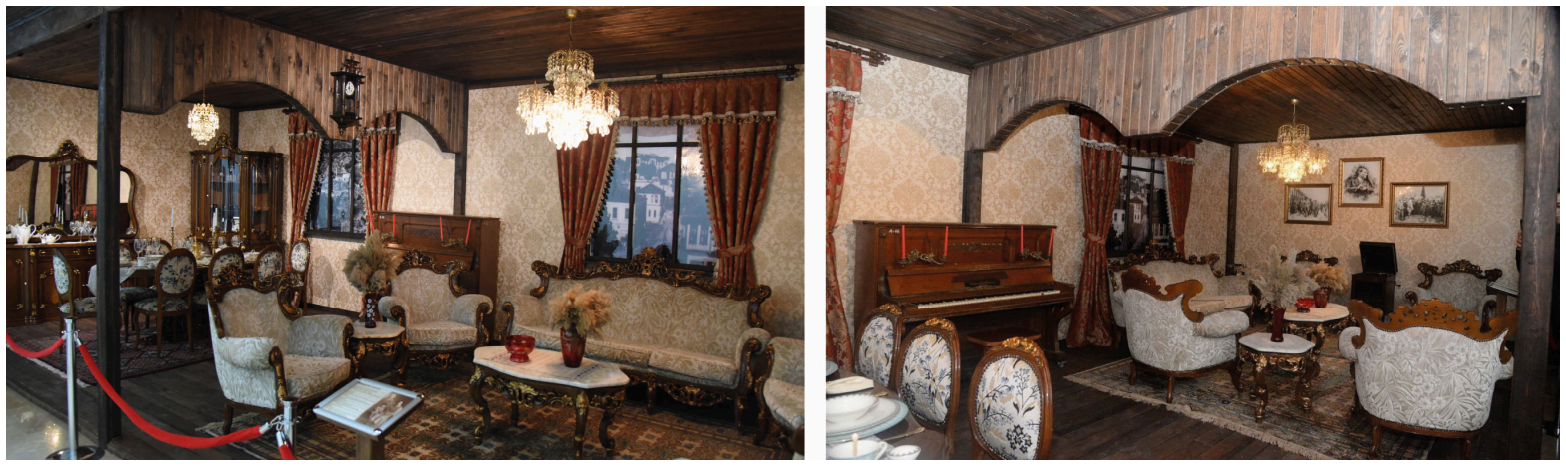

(Bilecik Belediyesi Yaşayan Şehir Müzesi, t.y.c).

Müzede çağdaş sergileme yöntemleri kapsamında ziyaretçilerin faydalanabilmesi adına bilgi sorgulama (kiosk) cihazları (Görsel 8), 3D sinema izleme alanları, Bilecik Tarihi ve Fethi'ni konu alan belgesel gösterimleri plazma ve led televizyonlar gibi teknolojik sistemler aracılığıyla ziyaretçilere sunulmaktadır. Ayrıca her ziyaretçinin bireysel olarak yöresel kıyafetlerle Görsel çektirebildiği, keyifli anılarla müzeden ayrıldığı Selfie Box Öz Çekim Alanı da müze içerisinde yerini almaktadır (Görsel 9). 


\section{Görsel 8}

Müze İçerisinde Yer Alan Kiosklar

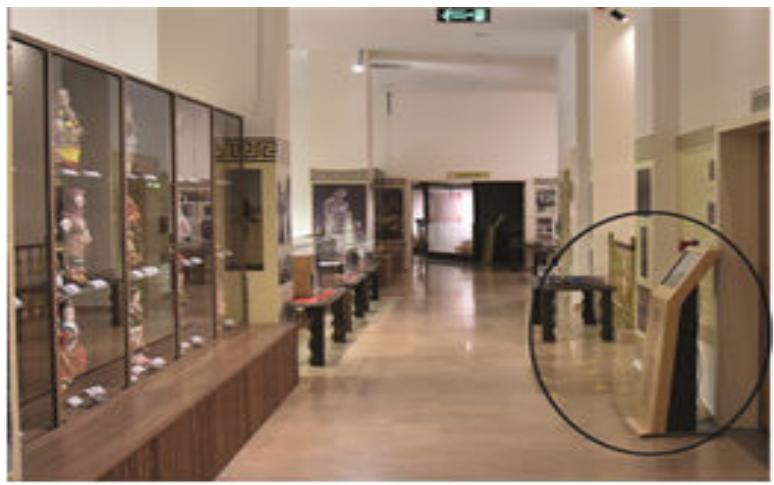

(Öztürk, t.y.e).

\section{Görsel 9}

Selfie Box Öz Çekim Alanı

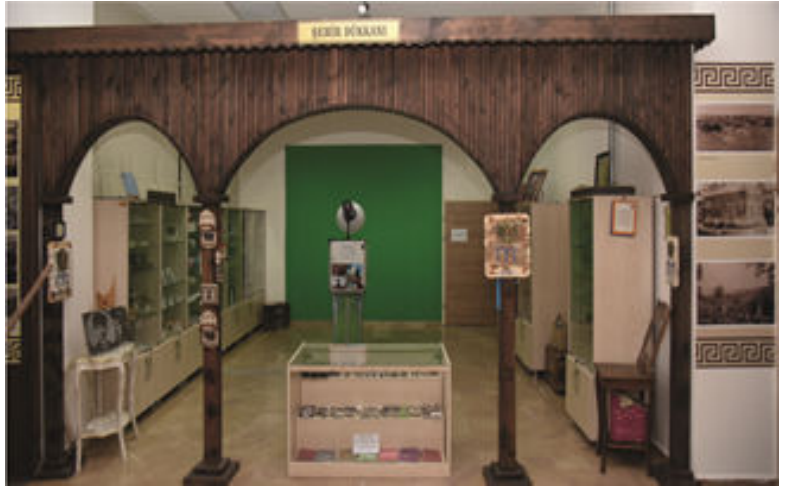

(Öztürk, t.y.f).

Müze içerisinde, sergilenen koleksiyonlara uygun iklimlendirme, akustik ve aydınlatma sistemleri kullanılmaktadır. Bilecik Belediyesi Yaşayan Şehir Müzesi bünyesinde; Yaşayan Şehir Müzesi Kitabı, Bilecik Belediyesi Yaşayan Şehir Müzesi Broşürü, Cep Haritası, 3 Boyutlu Bilecik Belgeseli bulunmakta ve müze bünyesinde gerçekleştirilen haberler ve etkinlikler sosyal medya ağları ile desteklenmektedir.

\subsection{Bilecik Belediyesi Yaşayan Şehir Müzesi'nin Etkinlikleri}

Modern müzecilik anlayışı, toplumun her kesimine hitap eden programlar, etkinlikler ile müzelerin bir kültür merkezi olarak toplumla bütünleşmesini sağlanmaya yöneliktir. Bilecik Belediyesi Yaşayan Şehir Müzesi'nde de belirli günlerde etkinlikler düzenlenmektedir. Gerçekleştirilen etkinlikler hem kültürün tanıtılması hem de yaşayarak öğrenmeye yönelik planlanmakta bu sayede öğrenciler ve halk tarafindan ilin kültürel, tarihsel ve geleneksel örf ve yaşanmışlıkları, yaşam tarzlarını yansıtan mirasın yapı taşlarını barındıran gelenek ve görenekleri tanıtılmakta, gelecek kuşaklara aktarılmaktadır.

Bilecik Belediyesi Yaşayan Şehir Müzesi açıldığı günden bu yana çok sayıda etkinlik düzenlemiş ve etkinliklerine aralıksız devam etmektedir. Müzenin etkinlikleri içerisinde: Geleneklerimizi Yaşatıyoruz Yaşatmaya Devam Ediyoruz, Ehl-i Sanat, Yöresel Lezzetler, Usta Parmaklar, Konuşan Eller Duyan Gözler Projeleri vb. kapsamında gerçekleştirilen pek çok etkinlik yer almaktadır. Ayrıca önemli günlerde düzenlenen etkinliklerle de Bilecik kültürünü tanıtılmaya devam etmektedir. Müzenin henüz web sitesi bulunmasa da sosyal medya hesaplarından etkinlikler duyurulmaktadır.

Bilecik Belediyesi Yaşayan Şehir Müzesi’nde yapılan etkinlik örnekleri olarak şunları sıralayabiliriz;

1. Kent Mutfağı Bölümü etkinlikleri kapsamında geleneksel tarife göre yapılan Osmanlı şerbeti ve Pazarcık helvası müzede ziyaretçilere ikram edilmektedir. Geleneksel Osmanlı şerbeti ve Pazarcık helvasının yapımını merak eden ziyaretçilere geleneksel lezzetlerimizin yapımı ile ilgili bilgi verilmektedir. Yine Kent Mutfağı etkinlikleri içerisinde “İstanbul'da Vefa varsa Bilecik'te Pazaryeri var” sloganı ile Bilecik' in Pazaryeri İlçesinin tanıtımı yapılmaktadır (Görsel 10). 


\section{Görsel 10}

Kent Mutfağının Tanıtılması Kapsamında Boza Etkinliği

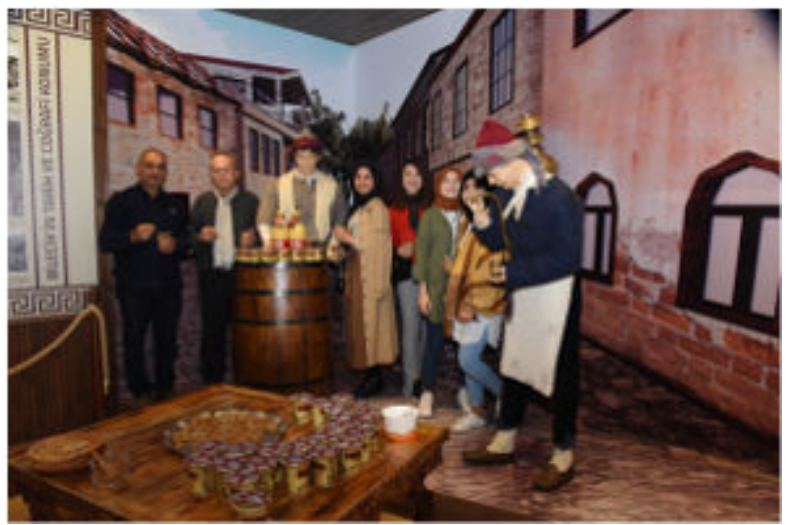

(Bilecik Belediyesi Yaşayan Şehir Müzesi, t.y.d).

2. "Usta Parmaklar" başlığı altında yapılan "Çömlekçilik" etkinliğinde müzeye davet edilen anaokulu, ilk, orta, lise öğrencilerine çömlek ustası tarafından geleneksel sanatın tanıtılması ile başlayan çalışmalar, öğrencilerin uygulama yapmasıyla tamamlanmaktadır. Etkinlik kapsamında öğrencilerin yaptığı çalışmalar ise sonrasında firınlanarak müzeden öğrencilere teslim edilmektedir (Görsel 11).

\section{Görsel 11}

Çömlekçilik Etkinliğinden

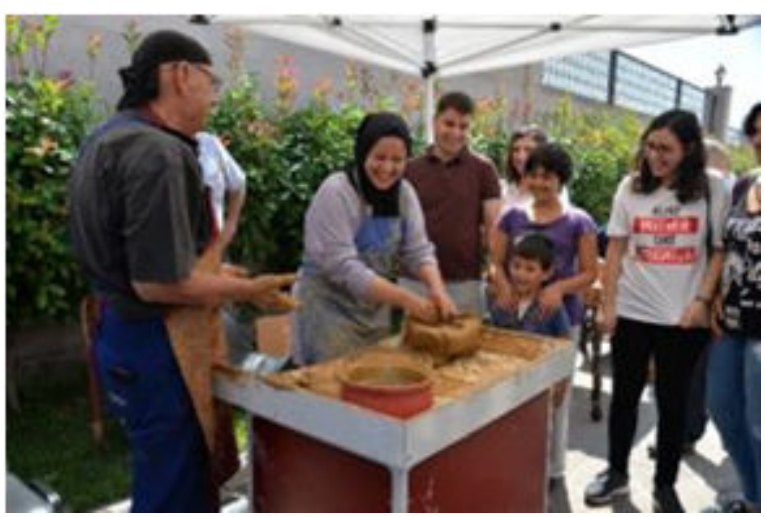

(Bilecik Belediyesi Yaşayan Şehir Müzesi, t.y.e).

3. "Yaşatmaya Devam Ediyoruz" başlığı altında “Arşivden Görsellarla Bilecik Sergisi” ile Bilecik'in geçmişi ve bugünü yaşatılmaktadır. "İpek Böcekçiliğii” etkinliğinde "Her Çocuğa Bir Koza” felsefesi ile ipekböceğinden kozanın oluşumuna kadarki süreç uygulama ile yaşatılmaktadır (Görsel 12). "Gazilerimiz Milli Mücadele Dönemini Anlatıyor" etkinliğinde Kıbrıs Gazileri yaşadıklarını anlatan konuşmalar yapmakta, dönem ruhu canlandırılarak yaşatılmaktadır.

\section{Görsel 12}

İpek Böcekçiliği ve İpek Çekme Etkinliğinden
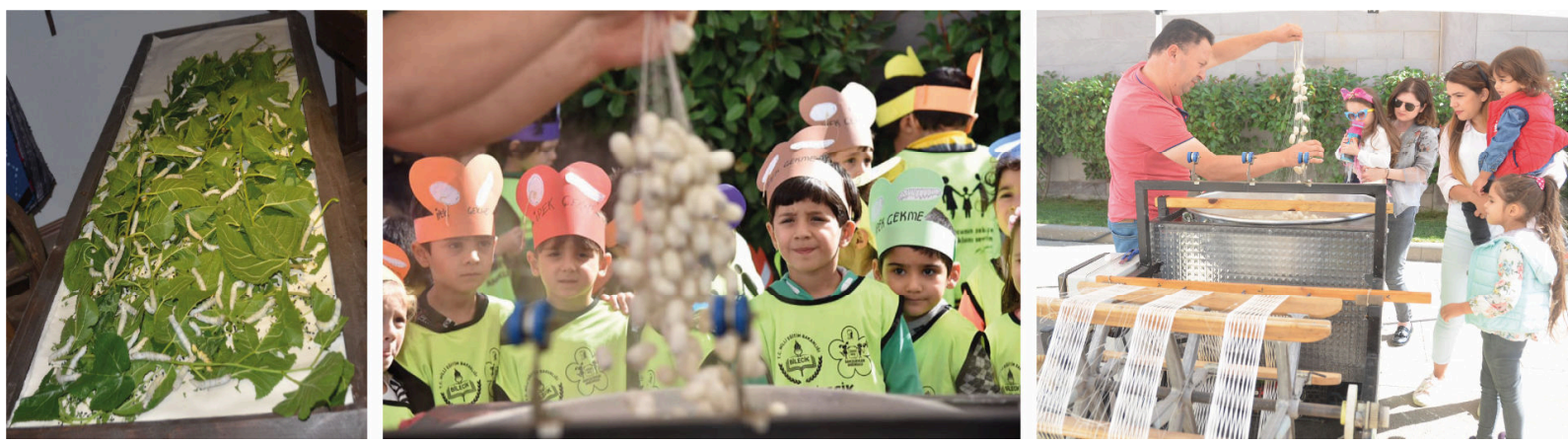

(Bilecik Belediyesi Yaşayan Şehir Müzesi, t.y.f). 


\section{Müzede Selfie Günü Etkinliği}

5. "Konuşan Eller Duyan Gözler” etkinliği kapsamında işitme engelli ziyaretçilere öğrenme potansiyeli yüksek müze ziyaretleri yaptırılmaktadır (Muhlis Aydemir, kişisel görüşme, Eylül 2020). Yine etkileyici sunumlar ve öğretiler kapsamında sayabileceğimiz diğer bir uygulama da, müzenin içerisinde yöreye özgü kıyafetlerle dantel ören kadınları, müze ziyaretçilerinin canlı canlı izleme ve kadınlar ile sohbet ederek merak ettiklerini sorup öğrenme imkanı bulması uygulaması gösterilebilir.

\section{Grafik 1}

2019 Yılı Yaşayan Şehir Müzesi Ziyaretçi Sayısı

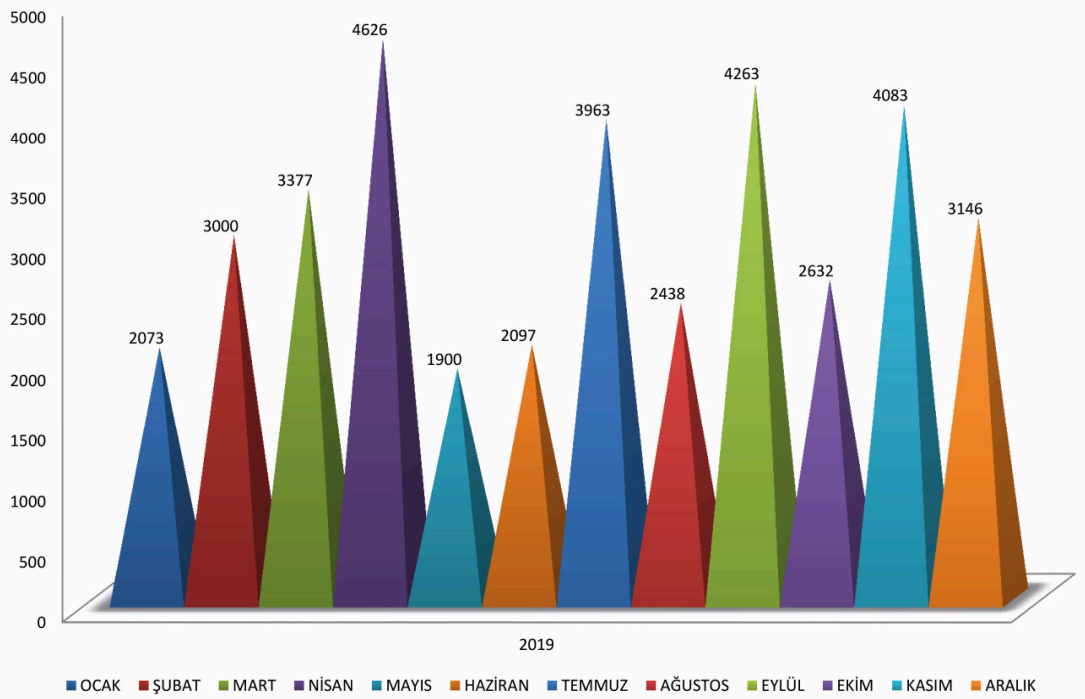

(Bilecik Belediyesi Yaşayan Şehir Müzesi, t.y.g).

Gerçekleştirilen etkinliklerde teknolojik gelişmeler de yakından takip edilerek, müze içerisinde hem sergileme hem de etkinliklerde farklı yöntemler geliştirilerek ziyaretçilerin ilgisini çekerek ziyaretçi sayısının $\operatorname{arttırdığ~}$ gözlenmiştir. Tablo 1'de 2019 yılına ait ziyaretçi sayısının aylara göre dağılımı grafikle gösterilmektedir. Bilecik Belediyesi Yaşayan Şehir Müzesi tarafından gerçekleştirilen etkinlikler müzeye gelen ziyaretçi sayısını da etkilemiştir.

Bilecik Belediyesi Yaşayan Şehir Müzesi’nde "Müze Akademi” kurulmaktadır. Ekim, Kasım, Aralık, Ocak 2020 aylarını kapsayan müze akademi programı oluşturulmuştur (Görsel 13). Müze Belediyenin sanat akademisi ile işbirliği yaparak; müze içerisinde sanat köşesi kurulacaktır. Çocuklar her Çarşamba Belediye binasında Sanat Akademi Biriminde birimin hocaları tarafından enstrümanlarla ilgili bilgi alacak (her hafta farklı bir enstrüman ile ilgili bilgilendirme yapılacak, bağlama, klarnet, yan flüt, bateri, piano, gitar, keman gibi), aynı gün hocalar müzede bilgisi verilen enstrüman ile çocuklara bir dinleti yapacaklardır.

\section{Görsel 13}

Bilecik Belediyesi Yaşayan Şehir Müzesi’nde Müze Akademi ve Etkinlikleri
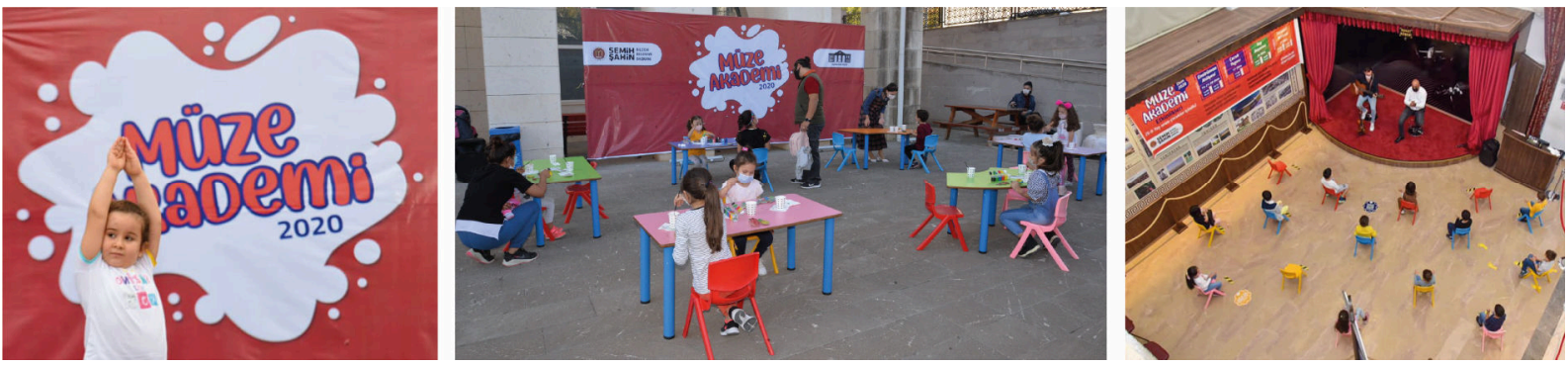

(Bilecik Belediyesi Yaşayan Şehir Müzesi, t.y.h).

Dört aylık program sonunda çocuklar müzede bir konser verip sertifikalarını alacaklardır. Amaç çocuk senfoni orkestrasının temellerini atmaktır. Çocuklar isterlerse hafta sonu istedikleri enstrümana yönelik belediyede sanat akademi biriminde ücretsiz kurs alabileceklerdir. Çocuklara yönelik Cumartesi günleri müzenin bahçesinde ya da içeride süreli sergi salonunda: çömlek atölyesi, koza çekme, taş boyama, anneler ve çocukları yarışıyor programı, çocuk yoga ve müzede müzik etkinlikleri yapılacaktır (her hafta bir etkinlik). Etkinlikler okullarla bağlantı kurulup programlanacaktır. Çocuklar müzeye Çarşamba okul hocalarıyla, Cumartesi aileleri ile gelecek ve etkinliğe 
katılacaktır. Müzede, Çarşamba günleri birer saatlik 9 ayrı gruba 4 aylık bir program yapılacak, Cumartesi ailelere yönelik müzede yapılacak Cumartesi etkinlikleri için aileler kayıt yaptırarak katılabilecekler, gruplar en az 10, en fazla 15 kişiden oluşacaktır (Mesut Ünver, kişisel görüşme, Eylül 2020).

\section{Tablo 1}

2020 Yılı Gerçekleştirilen Etkinlik Programı

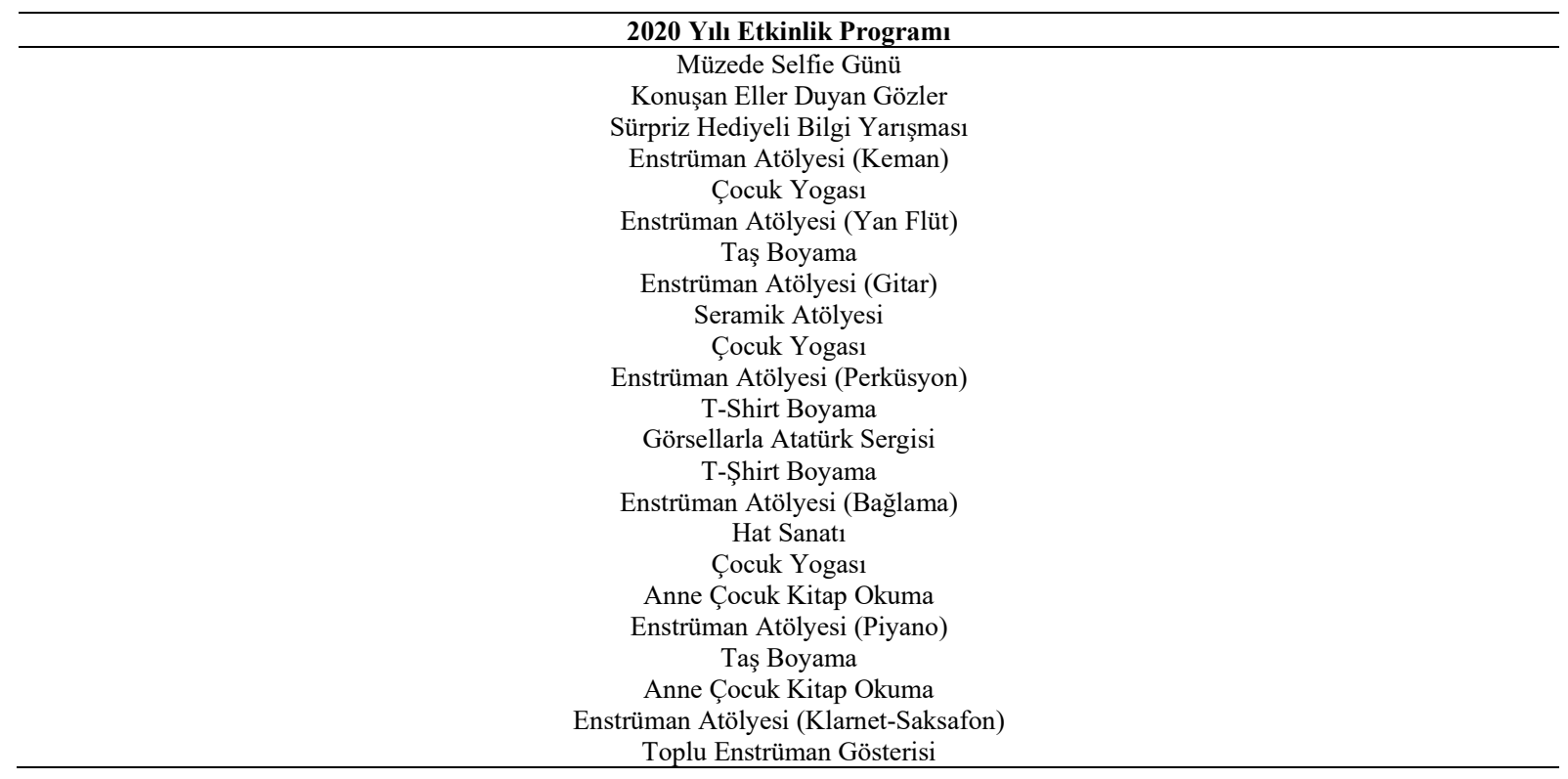

(Bilecik Belediyesi Yaşayan Şehir Müzesi, t.y.1).

Bilecik Belediyesi Yaşayan Şehir Müzesinde, Müze Akademi Projesi yaşama geçirilmiş ancak yaşanan salgın hastalıktan dolayı 2020 yılı Kasım ayının ortasında müze geçici bir süre kapatılmış etkinlilere ara verilmiştir.

\section{Sonuç, Tartışma ve Öneriler}

Müzeler içinde yaşattıkları dünyayı izleyicisine en etkileyici sunan öğrenme mekanlarıdır. Yine müzeler, yaşama dair geçmiş, bugün, gelecek sentezinin yapılabildiği, özellikle insanoğluna ait her tür (aile yapısı, gelenek, görenek, inanç, meslekler, sanat, teknoloji gibi) değişimin ve gelişimin yaşandığ 1 yerlerdir. Özellikle kent müzeleri kentin tüm belleğini yansıtan, yaşatan mekanlardır. Bilecik Belediyesi Yaşayan Şehir Müzesi, Türkiye için, sınırlı imkânla önemli projeler yapılabildiğinin, kent müzelerinin kentli tarafından nasıl benimsendiğinin en güzel örneklerindendir. Özellikle, 2017 yılında halkın kullanımına sunulan müzede ziyaretçilere çeşitli aktivitelerle Bilecik ilinin geleneklerinin yaşatılması, öğretilmesi ve kent tarihinin aktarılmasına yönelik çalışmalar aralıksız devam etmektedir. Müzenin açılışından bu yana yürüttüğü organizasyonlar ve çeşitli aktivitelerin yanı sıra, 2018 yılında en iyi şehir müzesi ödülüne layık görülen Bilecik Belediyesi Yaşayan Şehir Müzesi, 2020 yılında düzenlenen Tarihi Kentler Birliği tarafından bu yıl 4'üncüsü düzenlenen Müze Özendirme Yarışmasında Kent Müzeleri kategorisinde ödüle layık görülmüştür. Müze, Bilecik kent kimliğini tanıtmaya yaşatmaya ve geleceğe aktarma konusunda çalışmalarını aralıksız devam ettirmektedir. Özellikle okullarla yaptıkları organizasyonlarda, öğrencilere farklı etkinliklerle heyecan verici öğrenme ortamları sunmakta, öğrencilerin Bilecik ili ve çevresinde yaşamış uygarlıkları, geleneksel sanatları, meslekleri ve kültürel yaşama yönelik değerleri öğrenmesinde önemli rol oynamaktadir.

Müzede sunulan dünyanın öğrenilmesinde hazırlanan etkinlikler ve farklı uygulamalar son derece önemlidir. Programlı bir müze ziyaretiyle, amaca yönelik hazırlanmış etkinliklerle yapılan müze ziyaretlerinde öğrenciler daha istekli, meraklı olmakta, daha kalıcı öğrenme gerçekleşmektedir (Buyurgan, 2004, s. 114; Buyurgan, 2009 , s. 1187-1189; Buyurgan ve Demirdelen, 2009, s. 575-576; Çakır İlhan, 2012, s. 21; Genç ve Buyurgan, 2018 , s. 698; Güler ve Buyurgan, 2009, s. 138; Okvuran, 2012, s. 46). Yeni bir yere gitmek, yeni insanlarla tanışmak bilgi toplamada yeni yaklaşımları denemek ve gerçek şeylerle karşılaşmak çok güdüleyici ve uyarıcı olabilmektedir (Greenhill Hooper, 1999, s. 175). Tran'a göre müzeler öğrenme ve öğretme mekanlarıdır. Bu mekanların özgür seçime ve değerlendirme yapmaya dayanan doğası öğrenmeyi desteklemekte ve geliştirmektedir. İnsanlar ve özellikle çocuklar doğuştan öğrenme isteğine sahiptirler, müze gibi informal çevreleri belirleyen özellikler öğrenmeye yönelik içsel güdüyü beslerler (aktaran Onur, 2012, s. 169). Özellikle gelişmiş ülkelerde müzede öğrenmenin kazanımları görüldükten sonra çocuk müzeleri, okul müzeleri kurulmaya başlanmıştır. Örneğin Ragged Okul Müzesi'nde öğrencilere okul, ev ve iş hayatına, Viktorya Dönemi okul kültürüne yönelik eşya ve düzenlemelerle geçmiş dönem öğretilmekte ve geçmiş geleceğe taşınmaktadır (Karadeniz ve Çıldır, 2014, s. 53- 
56). Bilecik Belediyesi Yaşayan Şehir Müzesi’nde gerçekleştirilmekte olan "Müze Akademi" Projesi ile öğrencilerin geçmiş, bugün, gelecek sentezi yapmaları, kültürün tanınması, korunması, gelecek kuşaklara aktarılmasında bilinçli rol oynaması hedeflenmektedir.

Bilecik Belediyesi Yaşayan Şehir Müzesi Bilecik’te yaşamış tüm uygarlıkları, Kurtuluş Savaşı sürecindeki mücadeleden izleri, Bilecik'in her alandaki hikayesini, sosyal, siyasal, kültürel izlerini gözler önüne seren, yok olmaya yüz tutmuş geleneksel sanatlarımızın, mesleklerin tanınmasında ve devamlılığında önemli rol oynayan, yaptığı etkinliklerle öğrenciler ve yetişkinlerin yaşamında etkili öğrenme ortamları sunan önemli kent müzelerimizdendir. Müze Türk kültürünün ülkemizde ve Dünya'da tanıtılmasında, korunmasında ve gelecek nesillere aktarılmasında önemli rol oynamaktadır.

Bilecik Belediyesi Yaşayan Şehir Müzesi her geçen gün etkili sergileme yöntemleri, projeler ve etkinliklerle yaşamın içerisinde daha fazla yer almakta, kapılarını yaşama ve izleyicilerine sonuna kadar açmaktadır.

Bilecik ilinin tanıtılmasında büyük rol oynayan Bilecik Belediyesi Yaşayan Şehir Müzesi aldığı ödüllerle de örnek müzelerimizdendir. Her alanda, geçmiş, bugün, gelecek sentezinin yapılmasında önemli rol oynayan kent müzelerinin gelişimi özenle sağlanmalı, ülkemizdeki kent müzeleri sayıları da artış göstererek çoğalmalıdır.

Bilecik Belediyesi Yaşayan Şehir Müzesi’nde etkileyici eğitim etkinlikleri yapılmaktadır. Bu etkinliklerin daha sistemli oluşturulması ve takibi için müzede eğitim birimi kurulması ve bu birimde müze eğitimcilerinin görev yapması sağlanmalıdır.

Müze web sitesi oluşturularak müzenin tüm oluşum sürecinin, yapılan etkinliklerin ve müze bünyesinde yer alan haberlerin sistemli olarak takibinin yapılması gerçekleştirilmelidir. 


\section{Kaynakça}

Akyol Kasapoğlu, P. (2020). Covid-19 küresel salgın dönemi ve sonrası müze etkinlikleri. Millî Folklor, 16(127), 72-86. https://dergipark.org.tr/tr/download/article-file/1192049

Albasan, I. (2020). Türkiye'de kent müzeciliği ve bu bağlamda İstanbul ve Roma Kent müzelerinin bir karşılaştırması. UNIMUSEUM, 3(1), 15-22. https://dergipark.org.tr/tr/pub/unimuseum/issue/55036/723705

Altunbaş A., \& Özdemir Ç. (2012). Çağdaş müzecilik anlayışı ve ülkemizde müzeler. Kültür ve Turizm Bakanlığl Teftiş Kurulu, 1-24. https://teftis.ktb.gov.tr/Eklenti/4655.makale.pdf

Andre, L., Durksen, T., \& Volman, M. L. (2017). Museums as avenues of learning for children: A decade of research. Learning Environments Research, 20, 47-76. https://doi.org/10.1007/s10984-016-9222-9

Bilecik Belediyesi Yaşayan Şehir Müzesi. (t.y.a). 3 boyutlu ay yıldız platformunun yer aldı̆̆ı kurtuluş odası [Fotoğraf]. Bilecik Belediyesi Yaşayan Şehir Müzesi Arşivi.

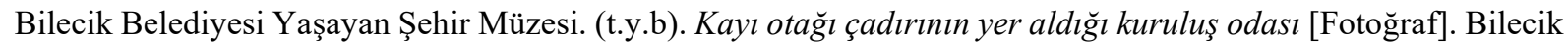
Belediyesi Yaşayan Şehir Müzesi Arşivi.

Bilecik Belediyesi Yaşayan Şehir Müzesi. (t.y.c). Cumhuriyet Odası [Fotoğraf]. Bilecik Belediyesi Yaşayan Şehir Müzesi Arşivi.

Bilecik Belediyesi Yaşayan Şehir Müzesi. (t.y.d). Kent mutfağının tanıtılması kapsamında boza etkinliği [Fotoğraf]. Bilecik Belediyesi Yaşayan Şehir Müzesi Arşivi.

Bilecik Belediyesi Yaşayan Şehir Müzesi. (t.y.e). Çömlekçilik etkinliğinden [Fotoğraf]. Bilecik Belediyesi Yaşayan Şehir Müzesi Arşivi.

Bilecik Belediyesi Yaşayan Şehir Müzesi. (t.y.f). Ipek böcekçiliği ve ipek çekme etkinliğinden [Fotoğraf]. Bilecik Belediyesi Yaşayan Şehir Müzesi Arşivi.

Bilecik Belediyesi Yaşayan Şehir Müzesi. (t.y.g). 2019 yılı Yaşayan Şehir Müzesi ziyaretçi sayısı [Grafik]. Bilecik Belediyesi Yaşayan Şehir Müzesi Arşivi.

Bilecik Belediyesi Yaşayan Şehir Müzesi. (t.y.h). Bilecik Belediyesi Yaşayan Şehir Müzesi’nde müze akademi ve etkinlikleri [Fotoğraf]. Bilecik Belediyesi Yaşayan Şehir Müzesi Arşivi.

Bilecik Belediyesi Yaşayan Şehir Müzesi. (t.y.1). 2020 yılı gerçekleştirilen etkinlik programı [Grafik]. Bilecik Belediyesi Yaşayan Şehir Müzesi Arşivi.

Bursa Büyükşehir Belediyesi. (t.y.). Bursa Kent Müzesi. https://www.bursamuze.com/bursa-kent-muzesi-496/

Buyurgan, S. (2004). Effective learning at the museum. The Journal of Cultural Research in Art Education, 22, 99-115. https://search.proquest.com/openview/25973cb4649fb9546f9600a635720cf4/1?pq-origsite=gscholar $\& \mathrm{cbl}=40077$

Buyurgan, S. (2009). The expectations of the visually impaired university students from museums. Educational Sciences: Theory\&Practice, 9(3), 1167-1204. https://files.eric.ed.gov/fulltext/EJ858923.pdf

Buyurgan, S., \& Buyurgan, U. (2020). Sanat eğitimi ve öğretimi (Ĕ̆itimin her kademesine yönelik yöntem ve tekniklerle (7. Bask1). Pegem Akademi. https://doi.org/10.14527/9786050370270

Buyurgan, S., \& Demirdelen, H. (2009). Total kör bir öğrencinin öğrenmesinde dokunma, işitsel bilgilendirme, hissetme ve müze. Türk Ĕ̈itim Bilimleri Dergisi, 7(3), 563-580. https://dergipark.org.tr/tr/download/articlefile/256279

Buyurgan, S., \& Mercin, L. (2010). Dünya'da ve Türkiye'de müzeciliğin ve müze eğitiminin tarihsel gelişimi. V. Özsoy (Ed.), Görsel sanatlar eğitiminde müze eğitimi ve uygulamalarl (s. 72-96) içinde. Öncü Basımevi.

Buyurgan, S., Tarlakazan, B. E., \& Çevik, S. K. (2019). Müzelerde sergileme yöntemleri. S. Buyurgan (Ed.), Müzede eğitim öğrenme ortamı olarak müzeler (s. 89-120) içinde. Pegem Akademi. https://doi.org/10.14527/ 9786052416372

Çakır İlhan, A. (2012). Yaratıcılık eğitimi bağlamında çocuk müzeleri. İ. San (Haz.), Çocuk müzeleri ve yaratıcı drama (s. 19-42) içinde. Naturel Yayıncılık.

Çekül Vakfı (2013). Kent tarihi müzeleri ve arşivleri. https://www.tarihikentlerbirligi.org/wp-content/uploads/ KentM\%C3\%BCzeleri-Ekitap.pdf 
Dönmez, B. M., \& Kılınçer, Z. (2011). Müziğin Yunan mitolojisi ve Batı kültürü içindeki algılanış1. İnönü Üniversitesi Sanat ve Tasarım Dergisi, 1(1), 101-113. https://dergipark.org.tr/en/download/article-file/799429

Erbay, M. (2011). Müzelerde sergileme ve sunum tekniklerinin planlanması. Beta Basım.

Eshach, H. (2007). Bridging in-school and out-of-school learning: Formal, non-formal and informal education. Journal of Science Education and Technology, 16(2), 171-190. https://doi.org/10.1007/s10956-006-9027-1

Genç, S., \& Buyurgan, S. (2018). Oyuna dayalı müze etkinliklerinin öğrenci erişi ve görsel sanatlar dersine karş1 tutumları üzerine etkisi. Inönü Üniversitesi Eğitim Fakültesi Dergisi, 19(3), 687-699. https://doi.org/10.17679/ inuefd. 440804

Gerçek, F. (1999). Türk müzeciliği. Türk Tarih Kurumu Basımevi.

Greenhill Hooper, E. (1999). Müze ve galeri ĕgitimi. B. Onur (Haz.), M. Örge Evren ve E. G. Kapçı (Çev.). A.Ü. Çocuk Kültürü Araştırma ve Uygulama Merkezi.

Güler, A., \& Buyurgan, S. (2009). İmpact of a planned museum tour designed via the employment of the museum education pack on the primary school students. European Journal of Educational Studies, 1(3), 133-144. https://www.yumpu.com/en/document/read/15727482/impact-of-a-planned-museum-tour-designed-via-ozea $\underline{\text { n-publications }}$

ICOM. (2019, 25 Temmuz). ICOM announces the alternative museum definition that will be subject to a vote. https://icom.museum/en/news/icom-announces-the-alternative-museum-definition-that-will-be-subject-to-avote/

İhtiyar, M. N. (2011). Çăgdaş müzecilik ve kent müzeciliği yeni bir program önerisi (Tez No. 327309) [Yüksek Lisans Tezi, İstanbul Teknik Üniversitesi]. Yüksek Öğretim Kurulu Tez Merkezi.

Karadeniz, C., \& Çıldır, Z. (2014). Ingiltere’de müze eğitimi: Londra'dan izlenimler. B. Onur (Haz.). Kalem Kitap.

Karasar, N. (1991). Bilimsel araştırma yöntemi (4. Basım). Sanem Matbaacılık.

Keskin, N. (2014). Kentlerde yeni bellek mekânları: kent müzeleri. Folklor ve Edebiyat Dergisi, 20(79), 25-39. https://dergipark.org.tr/en/download/article-file/255514

Köse, E. (2010). Uygulamalar ışı̆̆ında Türkiye'de kent müzeciliği kavramının değerlendirilmesi (Yayın No. 3985414) [Uzmanlık tezi]. https://docplayer.biz.tr/3985414-Uygulamalar-isiginda-turkiye-de-kentmuzeciligi-kavraminin-degerlendirilmesi.html

Mercin, L., \& Dilli, R. (2017). Bilecik Belediyesi Yaşayan Şehir Müzesi içerik yönetimi sanat tarihi eğitim ve danışmanlık teknik desteği projesi. Milli Ĕ̆itim Dergisi, 214, 407-414. https://dergipark.org.tr/tr/download/ article-file/441194

Okvuran, A. (2012). Çocuk müzeleri ve müzelerde yaratıcı drama eğitimi. İ. San (Haz.), Çocuk müzeleri ve yaratıcı drama (s. 43-55) içinde. Naturel Yayıncılık.

Onur, B. (2012). Çă̆daş müze eğitim ve gelişim müze psikolojisine giriş. İmge Kitabevi.

Öztürk, B. (t.y.a). Bilecik Belediyesi Yaşayan Şehir Müzesi dış mekân [Fotoğraf]. Büke Öztürk Arşivi.

Öztürk, B. (t.y.b). Müze içerisinden vitrin içi sergileme örnekleri [Fotoğraf]. Büke Öztürk Arşivi.

Öztürk, B. (t.y.c). Bilecik Belediyesi Yaşayan Şehir Müzesi üst kat görseli [Fotoğraf]. Büke Öztürk Arşivi.

Öztürk, B. (t.y.d). Müze içerisinde sepetçilik, yorgancılık, çömlekçilik, dokumacılık [Fotoğraf]. Büke Öztürk Arşivi.

Öztürk, B. (t.y.e). Müze içerisinde yer alan kiosklar [Fotoğraf]. Büke Öztürk Arşivi.

Öztürk, B. (t.y.f). Selfie box öz çekim alanı [Fotoğraf]. Büke Öztürk Arşivi.

Silier, O. (2010). Dünyada ve Türkiye'de kent müzeleri. Ege Mimarlı Dergisi, 16-21. http://www. egemimarlik. org/74/5.pdf

Sözen, M., \& Tanyeli, U. (1992). Sanat kavram ve terimleri sözlüğü. Remzi Kitabevi.

Şapolyo, E. B. (1936). Müzeler tarihi. Remzi Kitabevi.

Şenel Fidangenç, A. N. (2018). Discourse analysis of city museums in Turkey since 2000 (Tez No. 543124) [Doktora Tezi, İzmir Yüksek Teknoloji Enstitüsü]. Yüksek Öğretim Kurulu Tez Merkezi. 
T.C. Bilecik Belediyesi. (2019). Bilecik Belediyesi Yaşayan Şehir Müzesi tanıtım yazısı. https://www.facebook. com/yasayanmuzebilecik/

T.C. Bilecik Belediyesi. (2020). Bilecik Belediyesi Yaşayan Şehir Müzesi ödüle layık görüldü. https://www.bilecik. bel.tr/Haberler/45

T.C. Bilecik Valiliği. (t.y.). Söğüt. http://www.bilecik.gov.tr/sogut 